\title{
SEKOLAH ALAM DI MAKASSAR DENGAN KONSEP ARSITEKTUR BERKELANJUTAN
}

\author{
A.Abd. Wahab $\mathrm{S}^{1}$, Fahmyddin $\mathrm{AT}^{2}$, Taufik $\mathrm{Arfan}^{3}$ \\ Fakultas Sains \& Teknologi UIN Alauddin Makassar \\ E-mail ; fahmyddin@ hotmail.com, taufik.arfan@gmail.com
}

\begin{abstract}
Schools nature is a form of alternative education that uses nature as the main media as her students learning by using active or action learning where children learn through experience firsthand experience. The use of nature as a medium of learning is expected that in the future children or students more aware of the environment and know the application of knowledge learned, not only limited to theory. The design of this nature school also strengthened in view of Islam because it relates to science. In Islam has always emphasized learning activities and obligatory. Prompts Prophet, for every Muslim to seek knowledge should support the progressive development of human life, but within the limits of the pleasure of by Allah SWT. In addition, the most important thing of the study is how science is practiced for the good. digunskan concept in this design, combined with the study of literature and the state directly in the field and planned in the model concept and led to the idea of designing and developing desainnya. The results of the design adapted to local conditions acceptable to the environment and a recommendation for its development.
\end{abstract}

Keywords : school, nature, Architecture sustainable.

\footnotetext{
${ }^{1}$ Alumni Jurusan Teknik Arsitektur UIN Alauddin Makassar Angkatan 2008

${ }^{2}$ Dosen Jurusan Teknik Arsitektur UIN Alauddin Makassar

${ }^{3}$ Dosen Jurusan Teknik Arsitektur UIN Alauddin Makassar
} 


\section{PENDAHULUAN}

Sekolah memegang peranan penting dalam mengembangkan kemampuan kognitif, afektif dan psikomotorik para siswa. Sekolah yang berkualitas baik, akan menghasilkan lulusan yang baik pula. Begitu juga sebaliknya, sekolah yang buruk akan menghasilkan lulusan yang buruk. Sekolah juga perlu mengajarkan kepada para siswa tentang beberapa keterampilan hidup seperti saling menghormati, dan menghargai alam di mana kita hidup, pengembangan dan pelestarian seni budaya setempat menurut kebutuhan pengguna dan sesuai dengan standar perencanaan dan perancangan yang berlaku. Pendidikan harus sesuai dengan perkembangan pengajaran untuk anakanak harus dilakukan pada tingkat yang tidak terlalu sulit, terlalu menegangkan dan terlalu menjemukan. (Santrock.2008), Sehingga diperlukan proses pembelajaran yang menarik dan menyenangkan, karena secara lahiriyah anak lebih suka berada dalam ruangan informal, terbuka, dan bebas dibandingkan dengan suasana yang formal, tertutup dengan lingkungan terbatas.

Di kota Makassar, hampir semua sekolah dasar tidak mempergunakan lingkungan di sekitar untuk belajar. Yang mampu memberi beberapa keterampilan hidup. Sekolah yang mampu mengajarkan kemampuan memanfaatkan alam namun juga dapat memelihara alam untuk kehidupan selanjutnya. Sebagai hamba Allah jika kita mengaku beriman kepadaNya dan menginginkan derajat yang tinggi dibanding makhluk yang lain, maka perlulah kita untuk menuntut ilmu. Firman Allah dalam Al-Qur'an Surat Al-1Mujadilah Ayat 11, sebagai berikut:

"Allah akan meninggikan orang-orang yang beriman di antaramu dan orangorang yang diberi ilmu pengetahuan dengan beberapa derajat dan Allah Maha mengetahui apa yang kamu kerjakan'. (Q.S. Al-Mujadilah: 11).
Perancangan sekolah alam ini juga diperkuat dalam pandangan islam sebab berkaitan dengan ilmu pengetahuan. Dalam Islam aktivitas belajar selalu ditekankan dan wajib hukumnya. Kewajiban dalam menuntut ilmu dijelaskan oleh hadist berikut:

$$
\text { فريْضِة }
$$

Terjemahnya: 'Menuntut ilmu adalah fardhu bagi tiap-tiap muslim, baik laki-laki maupun perempuan'. (HR.Ibn. Abdilbarr).

Dari hadist Rasulullah SAW, dianjurkan bagi setiap muslim untuk menuntut ilmu pengetahuan yang dapat menunjang kemajuan perkembangan kehidupan manusia tetapi dalam batasan yang diridhohi oleh Allah SWT. Selain itu hal yang paling utama dari menuntut ilmu adalah bagaimana ilmu itu diamalkan untuk kebaikan. Selain lingkungan sekolah yang alami dengan ruang terbuka hijau yang dominan, aspek natural sekolah alam juga tampak pada desain struktur dan bahan bangunan yang digunakan. kepedulian dengan alam di sekitarnya, menjadi kesamaan ciri dari semua sekolah alam yang ada yang diwujudkan dengan bangunan sekolah yang ramah lingkungan. Hal inilah yang melatar belakangi sehingga Penulis mengangkat judul Sekolah Alam di Makassar dengan Konsep Arsitektur Berkelanjutan.

\section{TINJAUAN PUSTAKA}

\section{Pengertian Pendidikan}

Pendidikan (education) erat sekali dengan pembelajaran (learning), tujuan pendidikan pada umumnya adalah menyediakan lingkungan yang memungkinkan peserta didik untuk mengembangkan bakat dan kemampuannya secara optimal. Pendidikan bertanggung jawab untuk memandu serta memupuk, mengembangkan dan meningkatkan bakat tersebut (Nikrirotin. Latifah, 2007). Jenjang pendidikan di 
Indonesia sebagai mana diatur dalam UU no.2/1989 terdiri atas : Pendidikan Dasar, meliputi SD, MI dan yang sederajat (6 tahun) dan SLTP, MTS dan sederajat (3 tahun).Pendidikan Menengah, meliputi SLTA, MA dan sederajat (3 tahun), Pendidikan Tinggi, meliputi Perguruan Tinggi, Politeknik, Sekolah Tinggi dan sejenisnya. Selain itu, dapat diselenggarakan pula Pendidikan PraSekolah (1-2 tahun), dimana pendidikan pra-sekolah ini tidak merupakan persyaratan untuk memasuki pendidikan dasar (PP no 27' 1990 Bab 1, pasal 2). Bentuk satuan pendidikan pra-sekolah meliputi taman kanak-kanak, kelompok bermain, penitipan anak dan bentuk lainnya yang ditetapkan menteri. Taman Kanak-kanak terdapat di jalur pendidikan sekolah, sedangkan kelompok bermain dan penitipan anak terdapat di jalur pendidikan luar sekolah.

\section{Sekolah Alam}

\section{Pengertian Sekolah Alam}

Sekolah adalah bangunan atau lembaga untuk belajar dan mengajar serta tempat menerima dan memberi pelajaran. Menurut tingkatannya, terdiri dari dasar, lanjutan dan tinggi. Sedangkan menurut jurusannya, terbagi dalam bidang teknik, dagang, pertanian, dan sebagainya. Alam adalah segala yang ada di langit dan di bumi atau lingkungan kehidupan. (Kamus Besar Bahasa Indonesia, 2001). Sekolah alam adalah suatu tempat belajar yang berada di lingkungan alam yang masih sangat natural atau alami, yang menampung kegiatan belajar mengajar yang memiliki kurikulum tambahan tentang alam dan lingkungan hidup dalam proses pendidikannya. Menurut Efriyani Djuwita,M.Si, sekolah alam adalah salah satu bentuk pendidikan alternatif yang menggunakan alam sebagai media utama sebagai pembelajaran siswa didiknya. Tidak seperti sekolah biasa yang lebih banyak menggunakan metode belajar mengajar di dalam kelas, para siswa belajar lebih banyak di alam terbuka. Di sekolah alam metode belajar mengajar lebih banyak menggunakan aktif atau action learning dimana anak belajar melalui pengalaman (red- dimana anak mengalami dan melakukan langsung). Konsep sekolah alam adalah konsep belajar aktif, menyenangkan dengan menggunakan alam sebagai media langsung untuk belajar. Apabila sekolah alam mengacu pada pendidikan montesorri mungkin tidak bisa dikatakan mengacu seratus persen. Kelebihan sekolah alam dibandingkan sekolah biasa menurut psikologi UI ini, sekolah alam membuat anak tidak terpaku hanya pada teori saja. Di sekolah alam, biasanya aturan yang diberlakukan tidak seketat sekolah biasa dimana siswa harus duduk mendengarkan gurunya atau mendapatkan hukuman jika tidak mengerjakan tugas.

\section{Arsitektur Berkelanjutan}

Penerapan arsitektur berkelanjutan diantaranya; Dalam efisiensi penggunaan energy, memanfaatkan sinar matahari untuk pencahayaan alami secara maksimal pada siang hari, untuk mengurangi penggunaan energi listrik, memanfaatkan penghawaan alami sebagai ganti pengkondisian udara buatan (air conditioner), memanfaatkan air hujan dalam cara-cara inovatif untuk menampung dan mengolah air hujan untuk keperluan domestic. Dalam efisiensi penggunaan lahan, potensi hijau tumbuhan dalam lahan dapat digantikan atau dimaksimalkan dengan berbagai inovasi, misalnya pembuatan atap diatas bangunan (taman atap), taman gantung (dengan menggantung pot-pot tanaman pada sekitar bangunan), pagar tanaman atau yang dapat diisi dengan tanaman, dinding dengan taman pada dinding dan sebagainya, menghargai kehadiran tanaman yang ada di lahan, dengan tidak mudah menebang pohon-pohon, sehingga tumbuhan yang ada dapat menjadi bagian untuk berbagi dengan bangunan, desain terbuka dengan ruang-ruang yang terbuka ke taman (sesuai dengan fleksibilitas buka-tutup yang direncanakan sebelumnya) dapat menjadi 
inovasi untuk mengintegrasikan luar dan dalam bangunan, memberikan fleksibilitas ruang yang lebih besar.

\section{Studi Banding Sekolah Alam \\ Green School Bali}

Green School dirintis sejak tahun 2007

oleh John Hardy, Misinya adalah "memberdayakan warga global dan hijau inovator yang terinspirasi untuk mengambil tanggung jawab atas keberlanjutan.

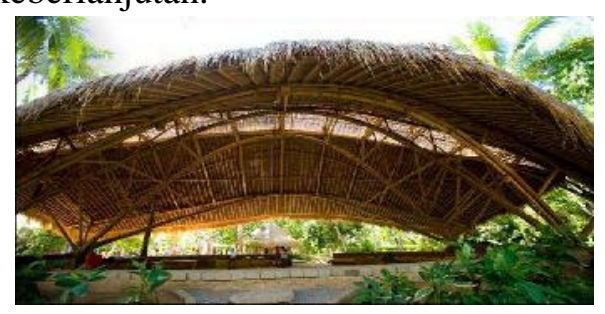

Gambar II.7: Ruang Kelas.

(Sumber://greenschool.org.html, diakses tanggal 27-12-2012).

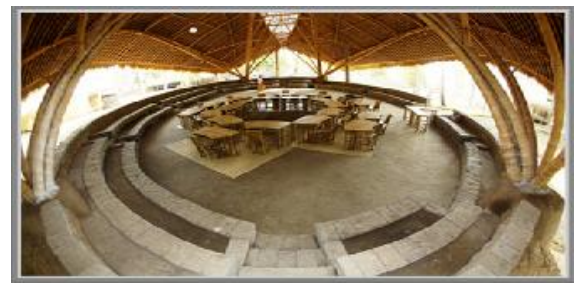

GambarII.8:Aulasumber://greenschool.org.htm 1, diakses tanggal 27-12-2012).

Hardy memutuskan untuk membuat sebuah sekolah yang akan berfungsi sebagai model bagi sekolah-sekolah di seluruh dunia dan mendidik anak-anak untuk menjadi pemimpin masa depan dalam memecahkan masalah yang terkait dengan keberlanjutan.

\section{METODE PERANCANGAN}

Metode yang digunakan dengan menggunakan metode survey dan study literature dengan pengaplikasikan langsung dalam konsep desain perancangan. Teknik pengambilan data dilakukan dengan survey lapangan melihat fakta yang ada dilapangan dan dianalisis dalam bentuk konsep desain untuk menghasilkan desain perancangan yang sesuai. Selain itu teknik pengambilan data juga dilakukan dengan wawacara langsung dan selanjutnya diolah untuk kemungkinan peruntukan desain yang tepat di dalam kawasan tersebut. Study literature juga digunakan disini untuk memberikan masukan berupa teoriteori pendekatan desain sekolah alam dengan konsep arsitektur berkelanjutan.

\section{HASIL PEMBAHASAN PENDEKATAN DESAIN}

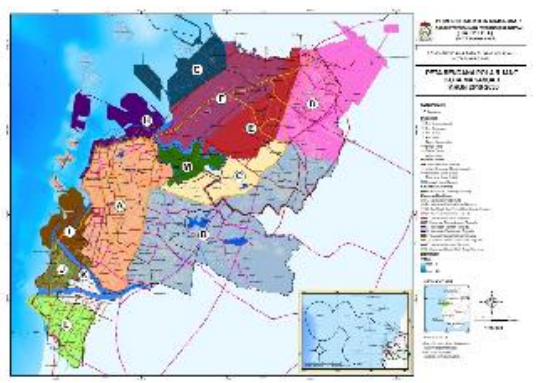

Gambar III.1: Peta Kota Makassar. (Sumber: Dinas Tata Ruang Kota Makassar, 2012)

Analisis Pengadaan Sekolah Alam di Makassar

\section{Tata Massa}

Agar tercipta tatanan ruang yang efektif dan sesuai kriteria perancangan maka, zona dalam ruang dibagi menjadi dua; Zoning ruang secara horizontal; Administrasi dan informasi, pengelola, Zona edukasi, Zona service, misalnya musholla, lavatory, gudang dan sejenisnya diletakkan berdekatan dengan ruang kelas, studio, ruang pengelola dan hall sehingga mudah dijangkau baik oleh pengelola, mahasiswa dan tenaga pengajar.

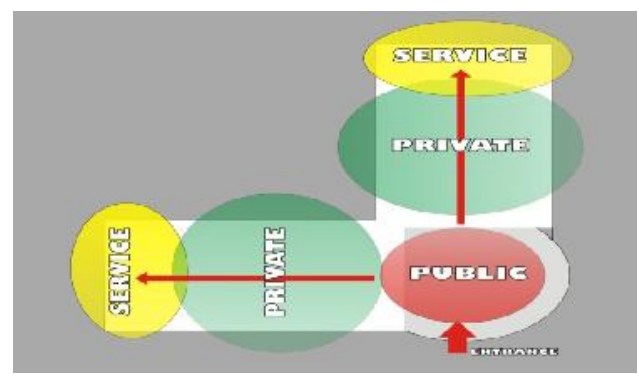

Gambar III.4 Zona Horizontal Bangunan. (Sumber:Dokumen Pribadi, 2013) 
Zoning ruang secara vertikal.

Ruang-ruang yang bersifat publik; ruang administrasi dan informasi diletakkan di lantai dasar. Ruang-ruang yang bersifat semi publik seperti ruang kelas, ruang perpustakaan, dan ruang serba guna diletakkan juga di lantai dasar sedangkan yang bersifat privat seperti ruang pimpinan dan ruang rapat diletakkan di lantai 2 dengan privasi yang tinggi.

Tapak

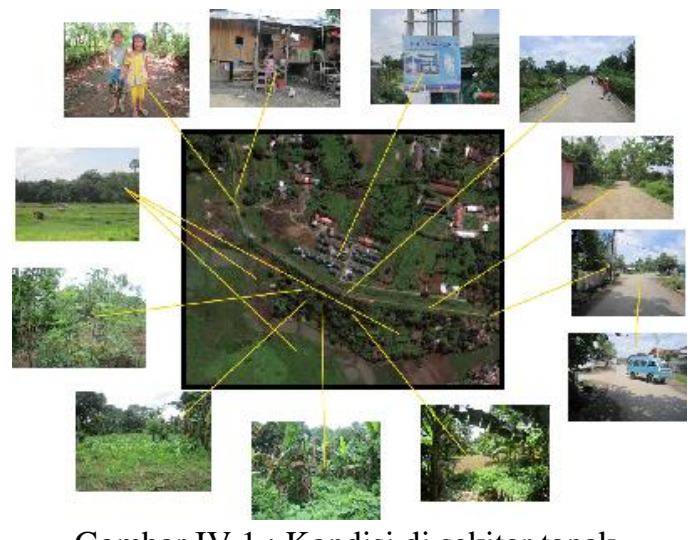

Gambar IV.1 : Kondisi di sekitar tapak

(Sumber: Data Pribadi, 2013)

Tata Lingkungan, kondisi Site/tapak bangunan sekolah alam berada di Kecamatan Manggala yang memiliki luas 2291,51 Ha, tepatnya di Jalan Inspeksi PAM, Kelurahan Antang dengan luas $526,84 \mathrm{Ha}$, yang fungsi utamanya sebagai pemukiman dan pendidikan sebagai fungsi penunjangnya.

\section{Potensi Tapak}

Kondisi lingkungan masih alami, dapat tumbuh berbagai vegetasi dan dijadikan empang guna mendukung sarana belajar, merupakan lahan kosong yang memiliki luasan cukup yang memadai. Berada pada kawasan pemukiman ataupun pendidikan, tersedianya jaringan utilitas kota, pencapaian mudah, nilai orientasi kenyamanan lingkungan arsitektural berupa view yang mendukung dari dan ke arah tapak, arah angin, lintasan matahari, serta tingkat kebisingan, polusi udara di sekitar tapak sedang.

\section{Ukuran dan Tata Wilayah Dimensi Tapak}

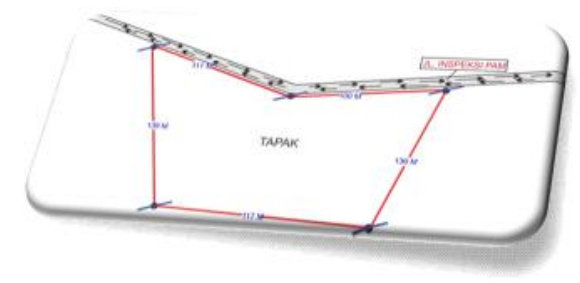

GambarIV.2. Kondisi eksisting ukuran tapak (Sumber: Data Pribadi, 2013)

Luas lahan $22.725 \mathrm{~m}^{2}$. Perbandingan Building Coverage (BC) yaitu perbandingan luas lahan terbangun dan tidak terbangun pada tapak menggunakan perbandingan $30 \%$ : $70 \%$.

\section{Analisis Tapak}

Kondisi Fisik Alamiah Tapak

Tabel IV.1 Analisis Kondisi Fisik Alamiah tapak

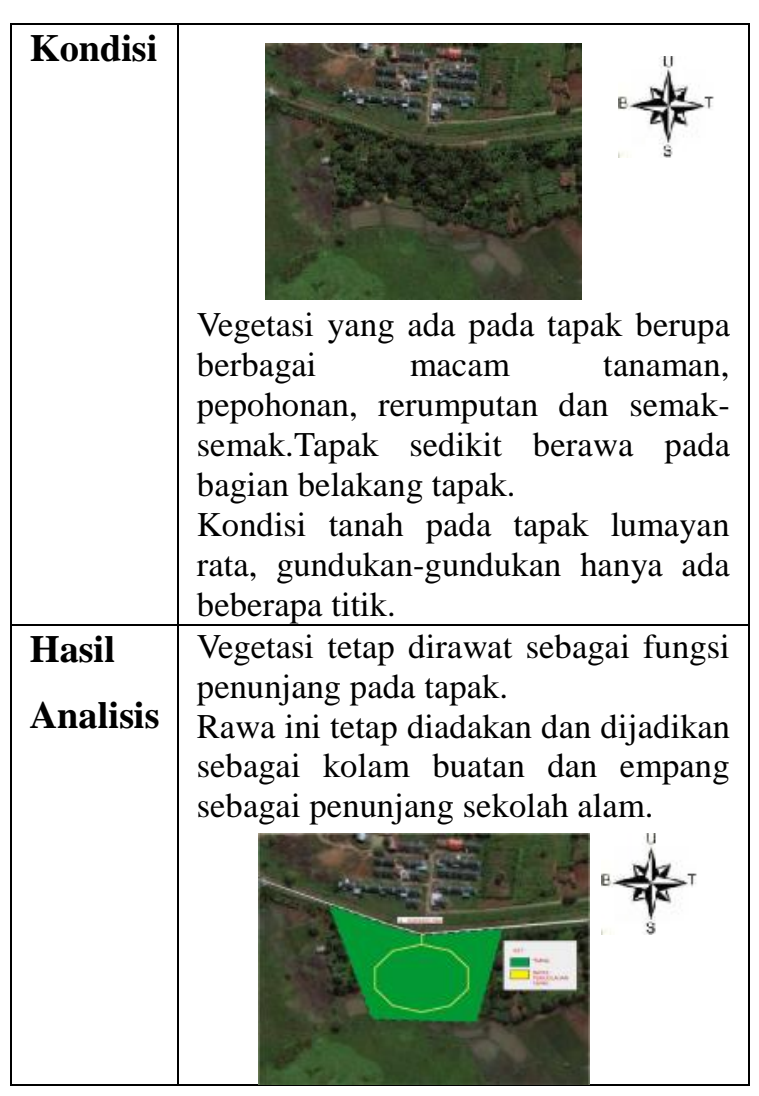

Sumber: Analisis Penulis,2013 
Nature

National Academic Journal of Architecture

Sirkulasi

Analisis sirkulasi menuju pada tapak diuraikan pada tabel berikut ini:

Tabel IV.2 : Analisis sirkulasi menuju tapak

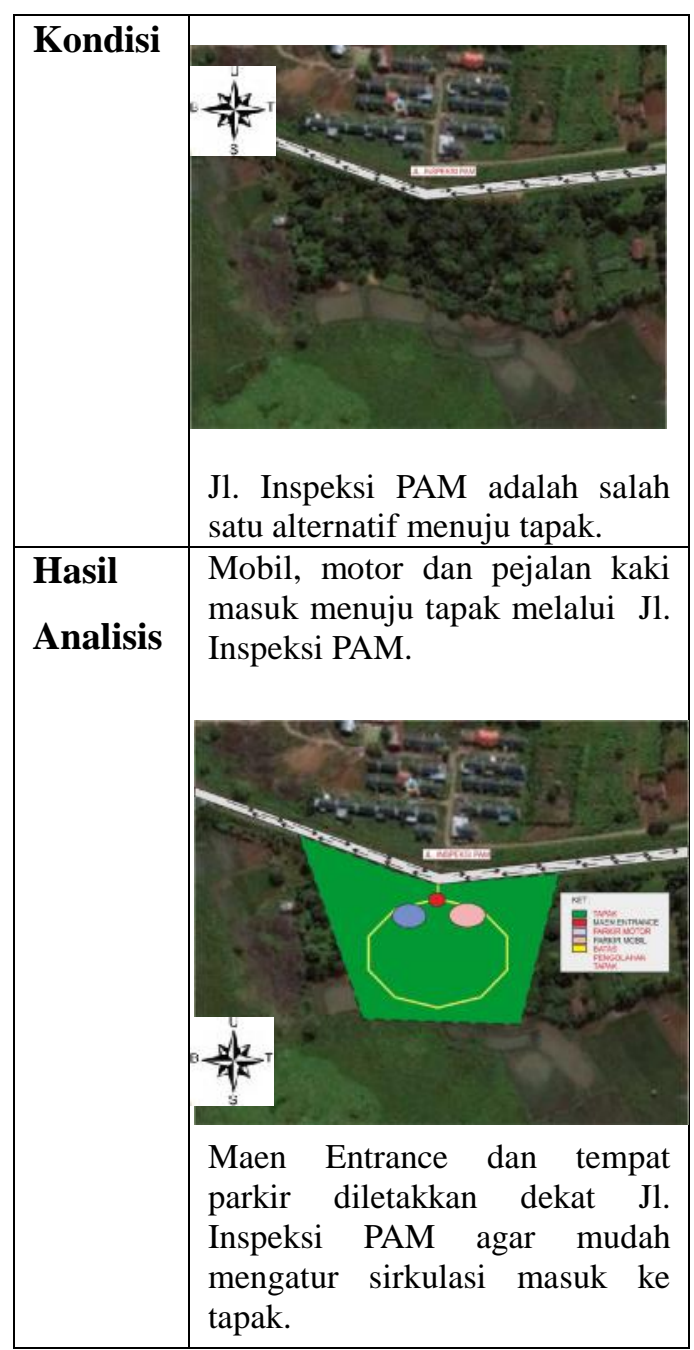

Sumber: Analisis Penulis, 2013
View

Analisis view pada tapak diuraikan pada tabel berikut ini:

Tabel IV.3.: Analisis View/pemandangan dari tapak

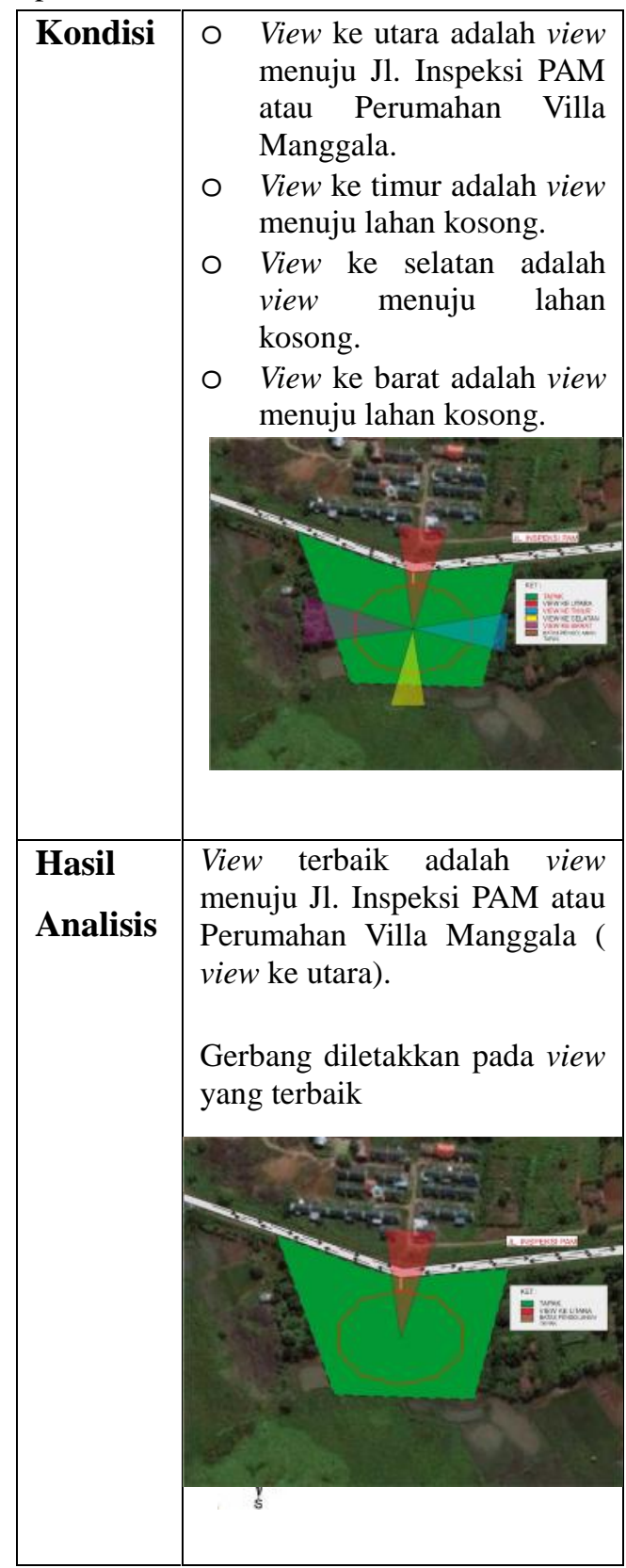

Sumber: Analisis Penulis, 2013 
Nature

National Academic Journal of Architecture

\section{Utilitas}

Analisis utilitas yang disediakan disekitar tapak diuraikan pada tabel berikut ini:

Tabel IV.4 : Analisis utilitas yang dilalui oleh tapak

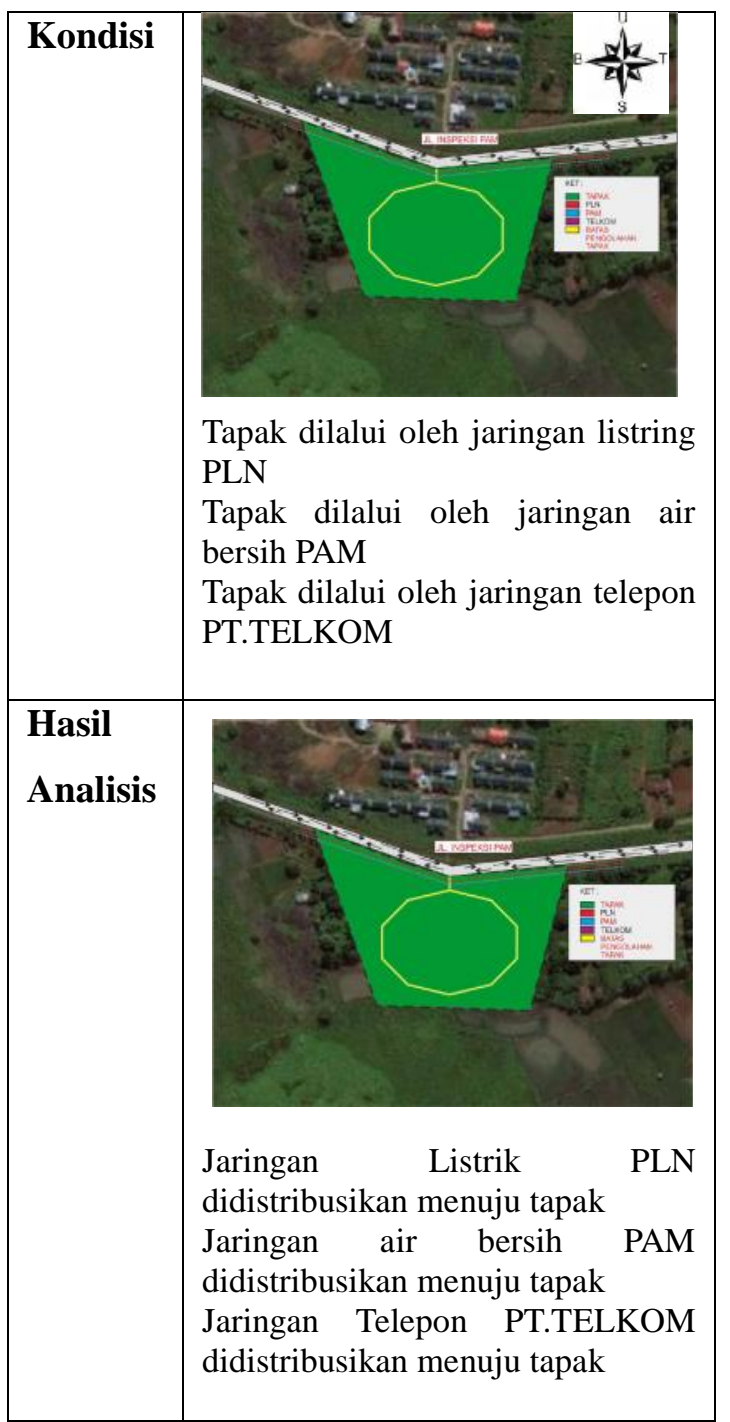

Sumber: Analisis Penulis, 2013

\section{Kebisingan}

Analisis kebisingan menuju tapak diuraikan pada tabel berikut ini:

Tabel IV.5 Analisis kebisingan pada tapak dan disekitarnya

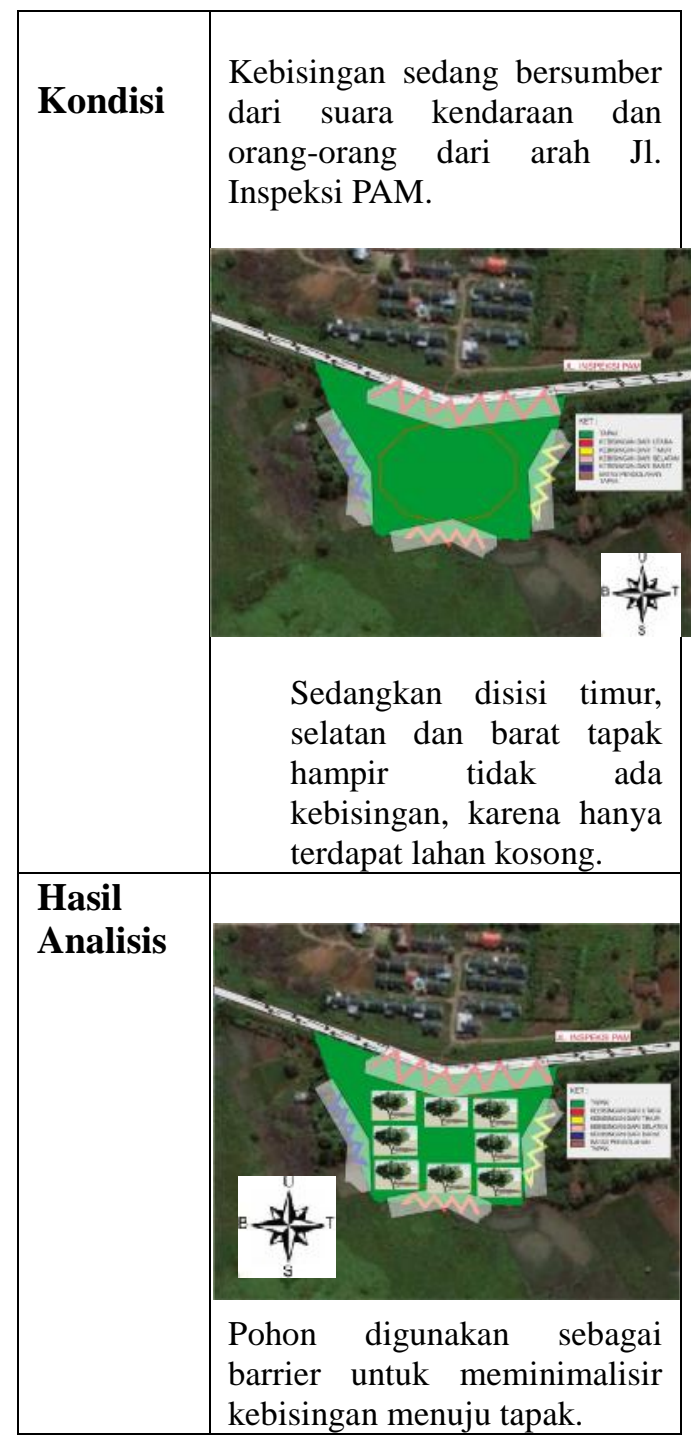

Sumber: Analisis Penulis, 2013 
Nature

National Academic Journal of Architecture

Iklim

Analisis iklim pada tapak diuraikan pada tabel berikut ini:

Tabel IV.6 : Analisis iklim pada tapak

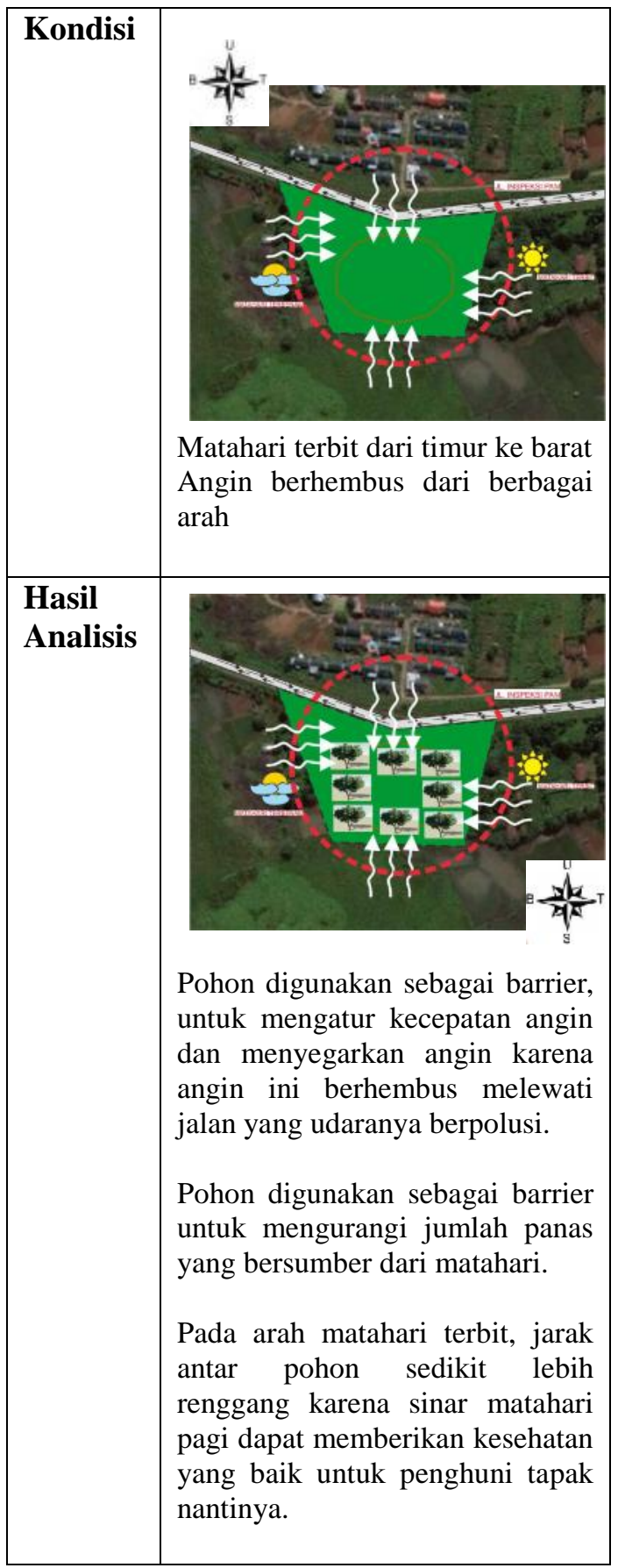

Sumber: Analisis Penulis, 2013

\section{Penzoningan}

Analisis penzoningan pada tapak diuraikan pada tabel berikut ini:

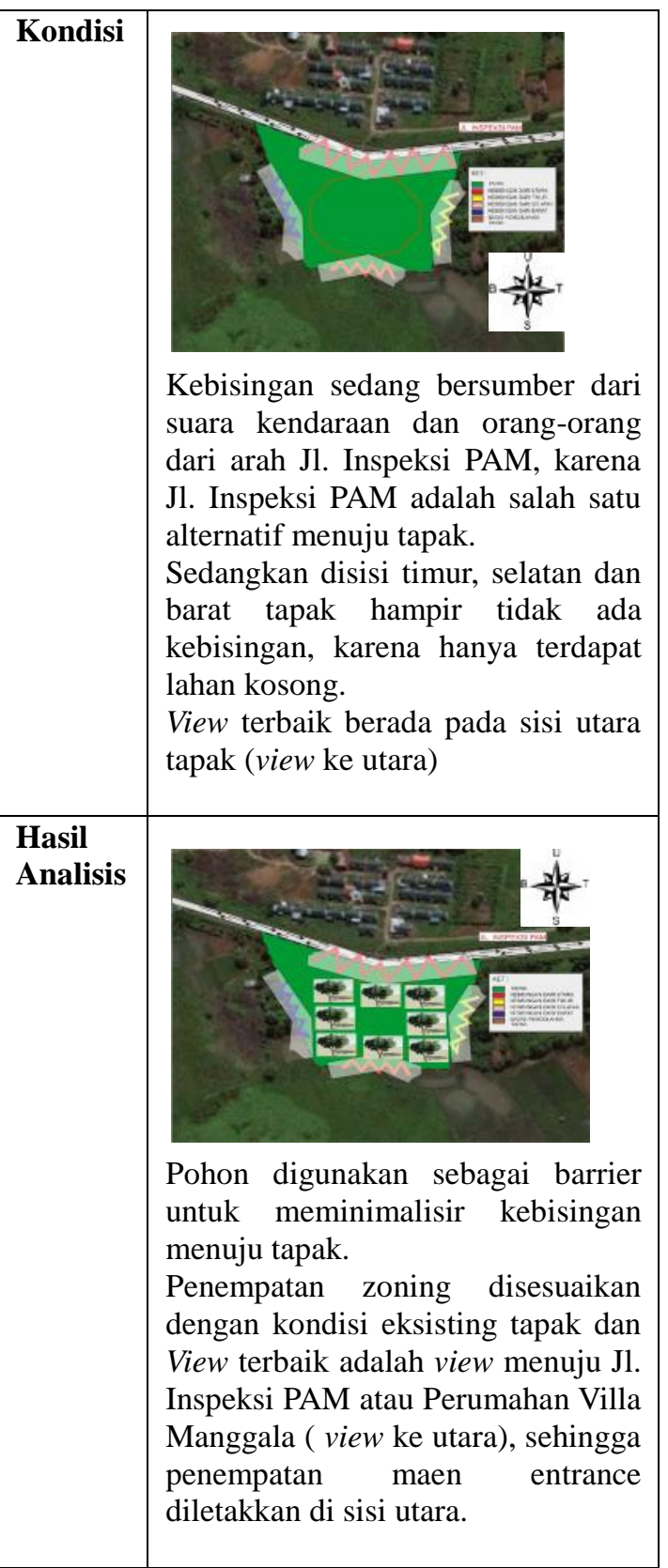

Sumber: Analisis Penulis, 2013

\section{Bentuk Dasar}

Konsep bentuk dan penampilan bangunan sekolah alam mengacu pada kondisi eksisting tapak dan konsep pendidikan yang diterapkan pada sekolah alam itu sendiri, yaitu konsep Spider Web. Bentuk dan penampilan bangunan yang diterapkan 
Nature

pada desain sekolah alam adalah sebagai berikut:

\section{Alternatif 1:}
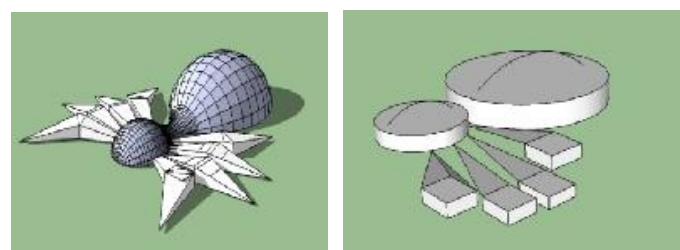

Gambar IV.4 Sketsa Transformasi Bentuk Fasade Sekolah Alam.

(Sumber:Dokumen Pribadi, 2013)

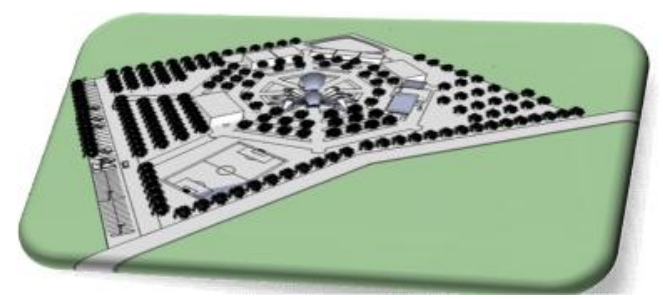

Gambar IV.5: Sinkronisasi antara tapak dan bentuk penampilan bangunan. (Sumber:Dokumen Pribadi, 2013)

\section{Alternatif 2:}
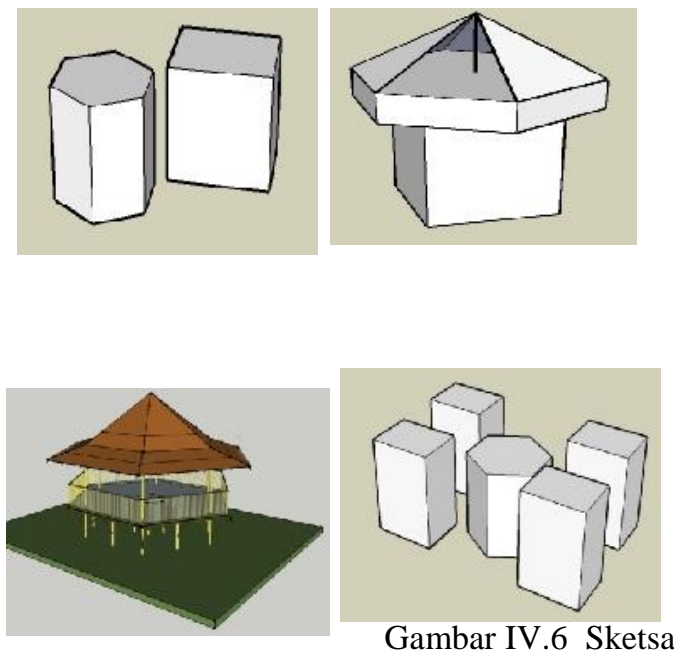

Transformasi Bentuk Fasade Sekolah Alam. (Sumber:Dokumen Pribadi, 2013)

\section{Struktur}

Bangunan Sekolah Alam ini merupakan bangunan bermassa. Penerapan strukturnya berupa pondasi, kolom, balok dan rangka atap yang menyesuaikan bentuk bangunan.

\section{Fondasi}

Fondasi yang digunakan pada bangunan ini adalah fondasi batu kali dan fondasi umpak. Fondasi batu kali berbentuk trapesium dengan ukuran tinggi $60-80 \mathrm{~cm}$ dan lebar pondasi atas $20-30 \mathrm{~cm}$.
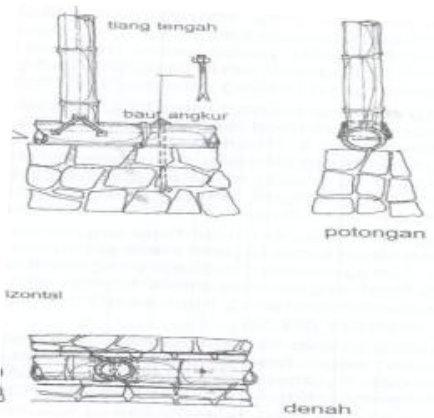

Gambar IV.8 Fondasi batu kali dengan material bambu sebagai dinding bangunan

(Frick,Heinz. 2004).

\section{Kolom}

Penggunaan material bambu dapat menggantikan beton bertulang bangunan berskala kecil. Bambu yang digunakan sebagai kolom pada bangunan biasanya bambu petung yang memiliki diameter 14 $-15 \mathrm{~cm}$.

\section{Pelat Lantai dengan Balok Batang Bambu}

Balok lantai batang bambu merupakan konstruksi bambu horizontal yang paling bawah sebagai penopang lantai. Balok loteng batang bambu dapat berfungsi sebagai konstruksi pembatas antara lantai paling atas dan ruang atap.

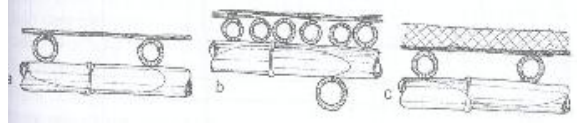

Gambar IV.10. Jarak dan susunan balok lantai di atas penggalang. 
Atap

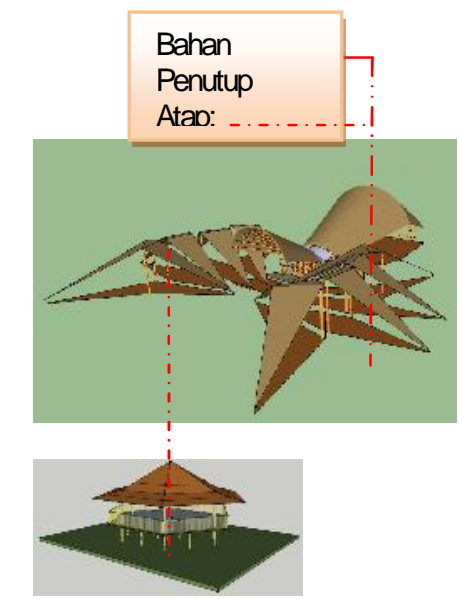

Gambar IV.11: Elemen atap bambu. (Sumber: Data Pribadi. 2013).

\section{Material}

Material dinding, Bambu untuk dinding di kreasikan dengan batang-batang bambu yang disusun berderet menyerupai jeruji dengan jarak yang teratur, baik rapat atau renggang.

\section{Material lantai dan plafon}

Penutup lantai dari bambu hampir menyerupai kayu olahan, seperti parket berbentuk lembaran dengan modul-modul berukuran tertentu. Modul ini biasanya berukuran $40 \times 120 \mathrm{~cm}$. Plafon dari bambu terdiri atas beberapa jenis, yaitu plafon biasa yang berfungsi menyembunyikan rangka atap dan plafon yang sekaligus berfungsi sebagai skylight. Plafon skylight punya pola renggang sehinga cahaya matahari dapat bisa masuk. Untuk jenis yang pertama, plafon umunya berupa lembaran anyaman atau bilik bambu seperti yang biasa digunakan di rumah-rumah tradisional. Untuk jenis yang kedua, bentuk potongan bambu dapat dikreasikan.

\section{Material pintu, dan jendela}

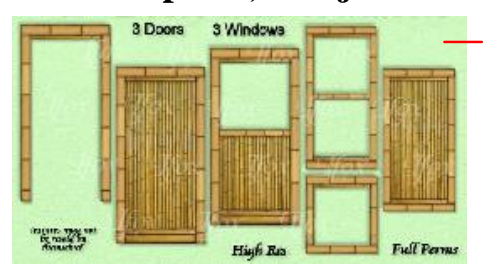

Gambar IV.15: Pintu dan jendela yang terbuat dari material bambu. (Sumber:

pintudanjendelabambu//.html, di akses tanggal 12-04-2013).

Material pintu dan jendela, daun pintu dan jendela beranyaman bambu yang digunakan pada konstruksi pintu yang berputar vertikal maupun sorong ke samping dibuat sebagai daun pintu panel. Bingkai terdiri dari bambu utuh $\varnothing>35$ $\mathrm{mm}$ yang dilengkapi dengan alur di bagian dalam daun pintu agar panel.

\section{/Utilitas}

\section{Sistem Plumbing}

Sistem penyediaan air bersih.

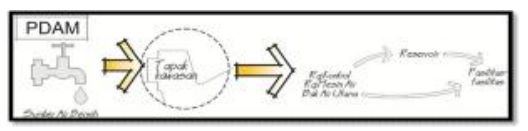

Gambar IV.16: Skema jaringan air bersih pada sekolah alam. (Sumber: Analisa Pribadi. 2013).

Sistem Pembuangan Sampah

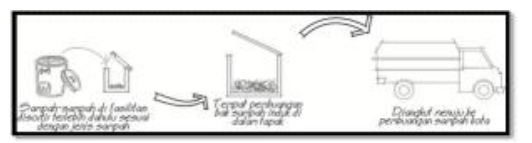

GambarIV.18: Skema pembuangan sampah pada sekolah alam. (Sumber: Analisa Pribadi. 2013).

Sistem pembuangan air kotor

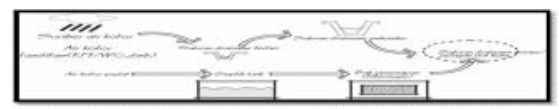

Gambar IV.17: Skema jaringan air kotor pada sekolah alam. (Sumber: Analisa Pribadi. 2013). 
Sistem Pengkondisian Bangunan

Pencahayaan Alami

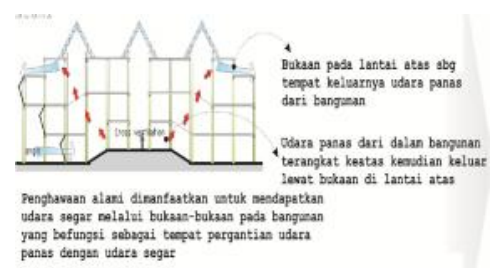

Gambar IV.19: Skema pencahayaa alamipada sekolah alam.(Sumber: Analisa Pribadi. 2013)

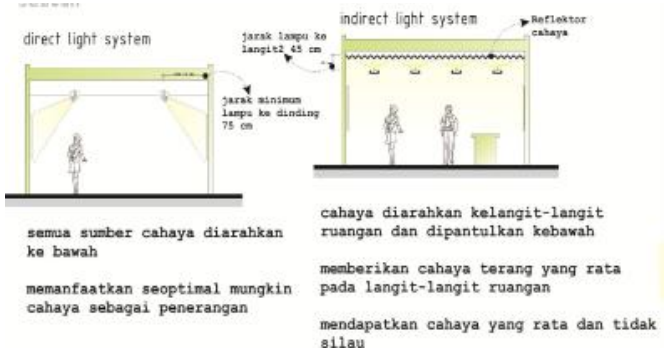

Pencahayaan Buatan

Gambar IV.20: Skema pencahayaan buatan pada sekolah alam. (Sumber: Analisa Pribadi. 2013).

\section{Penghawaan Buatan}

Sistem ini digunakan untuk melayani tiaptiap ruangan yang membutuhkan kenyamanan yang berbeda-beda.

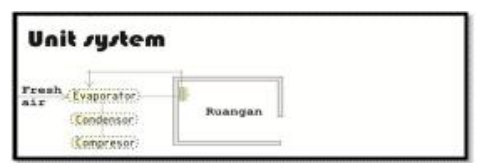

Gambar IV.22: Skema penghawaan buatan pada sekolah alam. (Sumber: Analisa Pribadi. 2013).

\section{Penghawaan Alami}

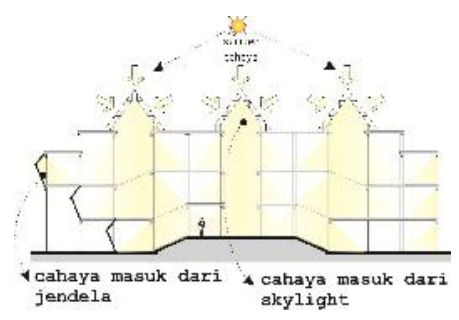

Gambar IV.21: Skema penghawaan alami pada sekolah alam.(Sumber: Analisa Pribadi. 2013).

\section{Sistem jaringan listrik}

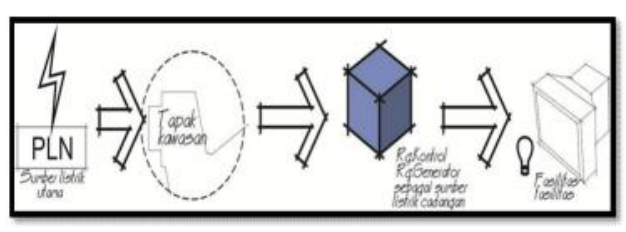

Gambar IV.23: Skema jaringan listrik pada sekolah alam. (Sumber: Analisa Pribadi. 2013).

\section{Sistem Keamanan}

Sistem Pencegah Kebakaran

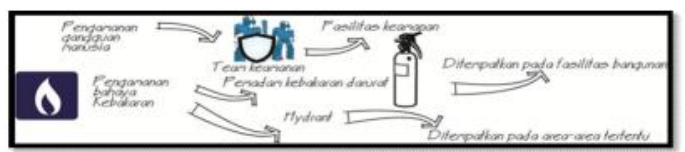

Gambar IV.24: Skema pencegahan kebakaran dan sistem pencegahan kriminal pada sekolah alam. (Sumber: Analisa Pribadi. 2013).

Sistem Penangkal Petir

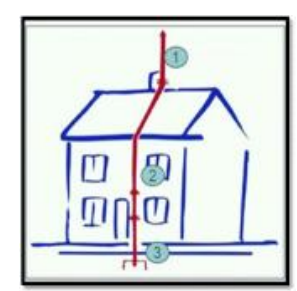

$$
\begin{aligned}
& \text { 1. Terminal Udara } \\
& \text { 2. Penghantar } \\
& \text { Turun } \\
& \text { 3. Tempat } \\
& \text { Domhımian }
\end{aligned}
$$

Gambar IV.25: Skema penangkal Sumber: Analisa Pribadi. 2013).

Sirkulasi Makro

\section{Entrance}

Entrance menuju bangunan disediakan akses tersendiri, untuk mempermudah pencapaian pada bangunan. Entrance sekolah alam diletakkan pada area sirkulasi Jl. Inspeksi PAM.

\section{Jalan dan pedestrian}

Perbedaan antara sirkulasi pejalan kaki dan kendaraan bermotor dalam site dengan jelas untuk menertibkan sirkulasi dengan pemberian vegetasi dan perkerasan sebagai pembatas.

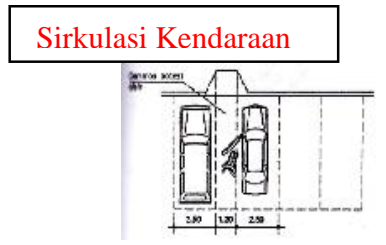

Gambar IV.26 : Sirkulasi menuju tapak (Sumber:dokumen pribadi, 2013) 


\section{Parkir}

Bentuk tempat parkir terdiri atas beberapa jenis, yaitu:

Parkir tegak lurus (perpandicular) dan Parkir sudut (angle).

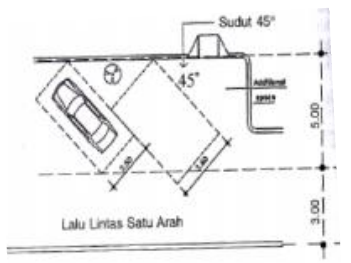

GambarIV.27.Parkir tegak lurus dan parkir sudut. (Sumber: Hakim, 2008)

\section{Sirkulasi Mikro}

\section{Sirkulasi horisontal}

merupakan merupakan jalan lalu-lalang antar ruang dalam satu lantai.

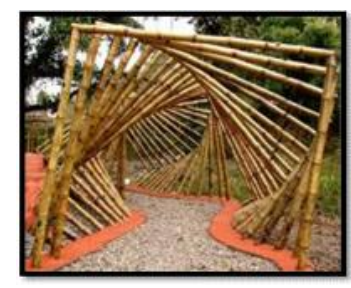

Gambar

IV.28:Koridor

Bambu

(Sumber:

www.bambukreasi//html, diakses tanggal 1205-2013).

Persentase kemiringan pada sirkulasi jenis ini tidak lebih dari $10 \%$, yang termasuk transportasi jenis ini adalah koridor dan konveyor.

\section{Sirkulasi vertikal}

Sirkulasi vertikal pada bangunan sekolah alam menghubungkan antara lantai yang satu dengan lantai yang lainnya. Jenis sirkulasi yang digunakan adalah berupa tangga.

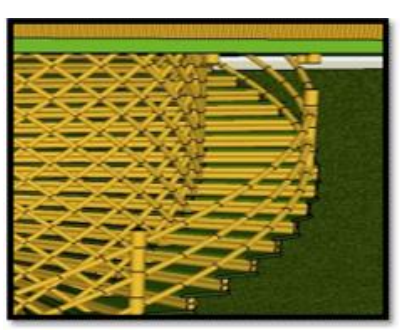

Gambar. IV.29

Tangga Bambu (Sumber: Data Pribadi. 2013).

\section{APLIKASI DESAIN \\ Blok Plan}

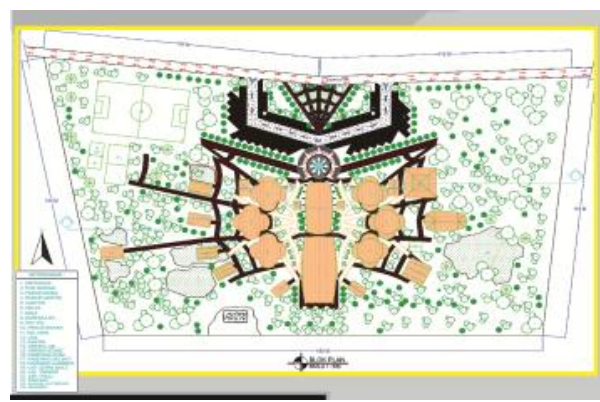

Gambar III.1: Blok Plan.(Sumber: Data Pribadi)

\section{Bangunan Utama \\ Kantor}

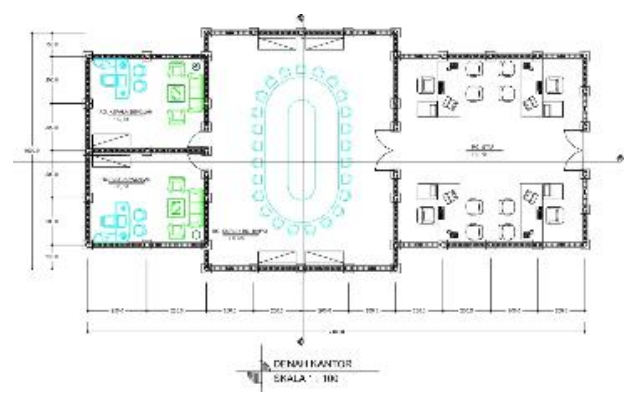

Gambar III.2: Denah Kantor.

(Sumber: Data Pribadi)

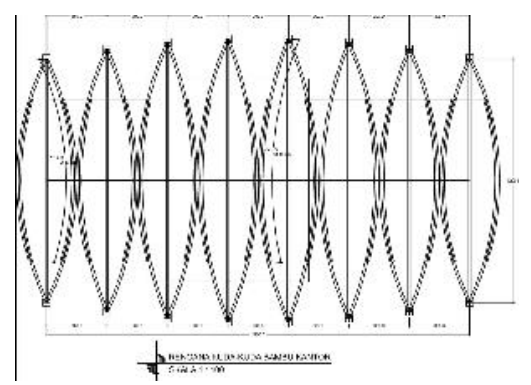

Gambar III.3: Rencana Kuda-kuda Kantor. (Sumber: Data Pribadi)

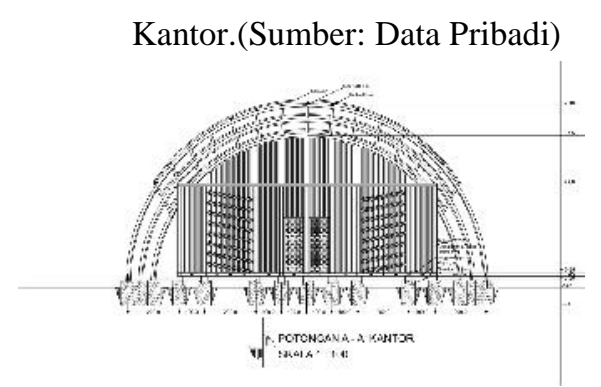


Nature

National Academic Journal of Architecture

III.4: Potongan A - A

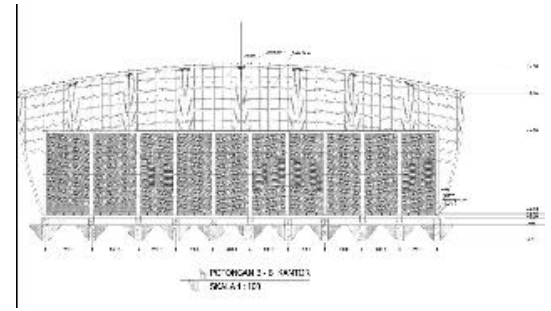

Gambar III.5: Potongan B - B Kantor. (Sumber: Data Pribadi)
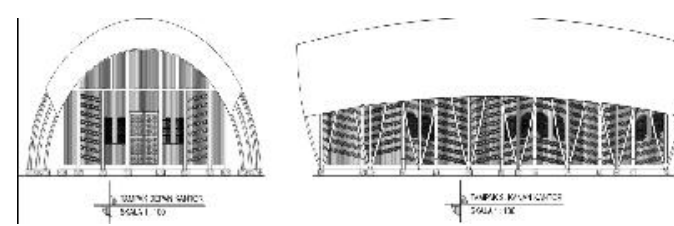

Gambar III.6: Tampak Kantor.

(Sumber: Data Pribadi)

\section{Kelas}
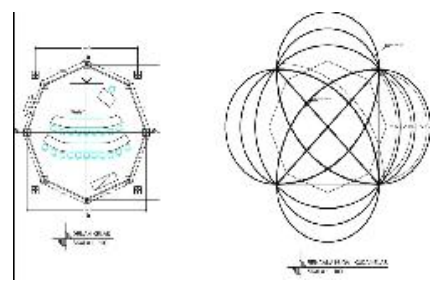

Gambar III.7: Denah dan Rencana Kuda-kuda Kelas. (Sumber: Data Pribadi)
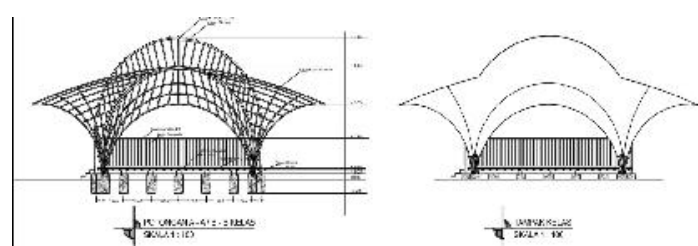

Gambar III.8: Potongan dan Tampak Kelas. (Sumber: Data Pribadi)

\section{Aula}

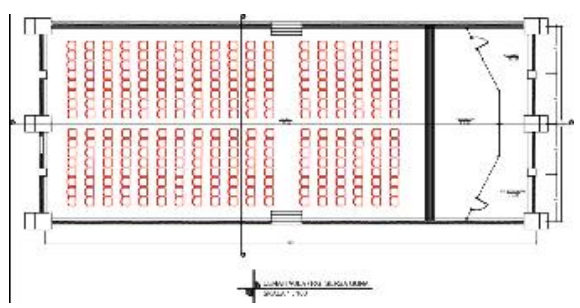

Gambar III.9: Denah Aula.

(Sumber: Data Pribadi)

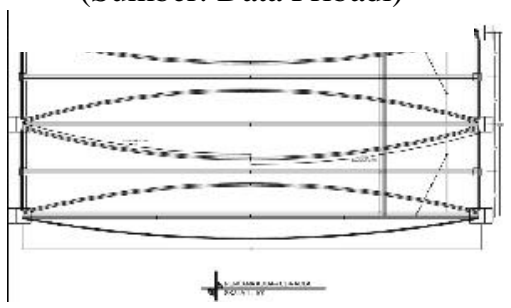

Gambar III.10: Rencana Kuda-kuda Aula.(Sumber: Data Pribadi, 2013)

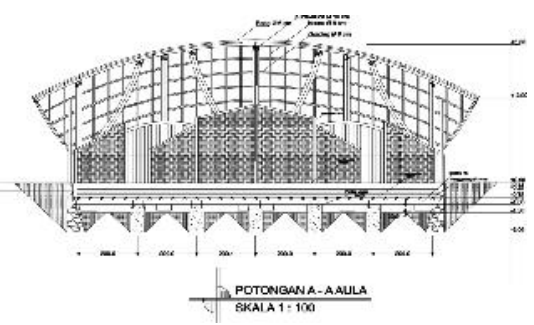

Gambar III.11: Potongan A - A Aula. (Sumber: Data Pribadi)

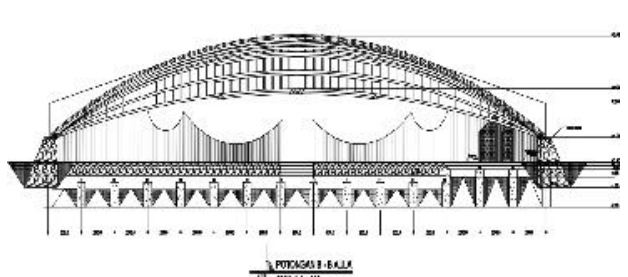

Gambar III.12: Potongan B - B Aula (Sumber: Data Pribadi)

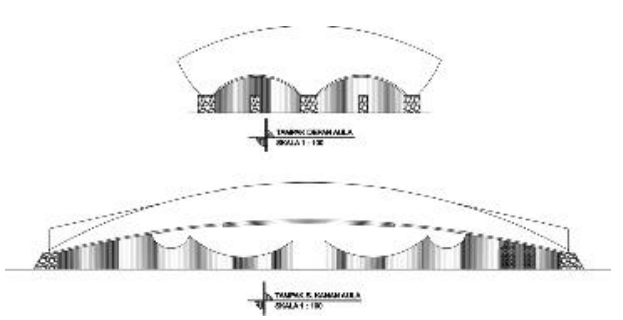

Gambar III.13: Tampak Aula. (Sumber: Data Pribadi)

\section{Bangunan Penunjang}
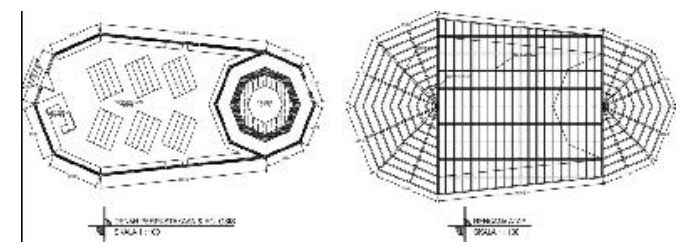
Gambar III.14: Perpustakaan. (Sumber: Data Pribadi)

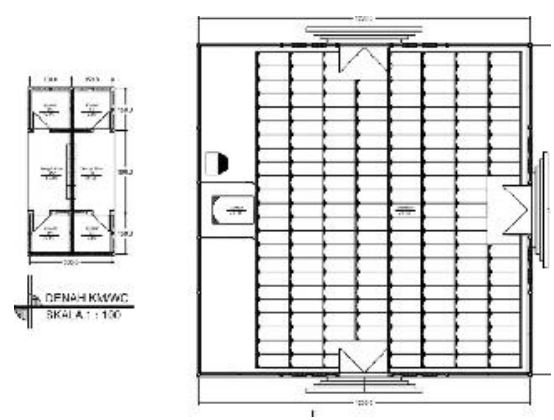

Gambar III.15: KM/WC, Mushollah. (Sumber: Data Pribadi)

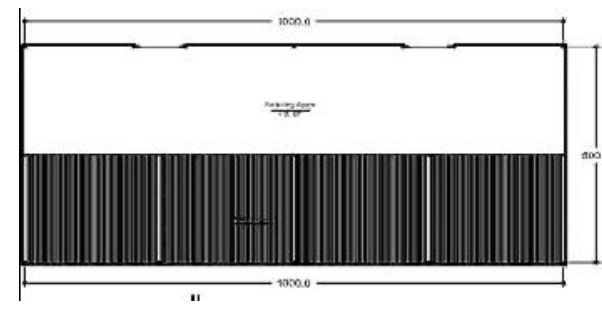

Gambar III.16: Kandang Ayam. (Sumber: Data Pribadi)

\section{Detail}
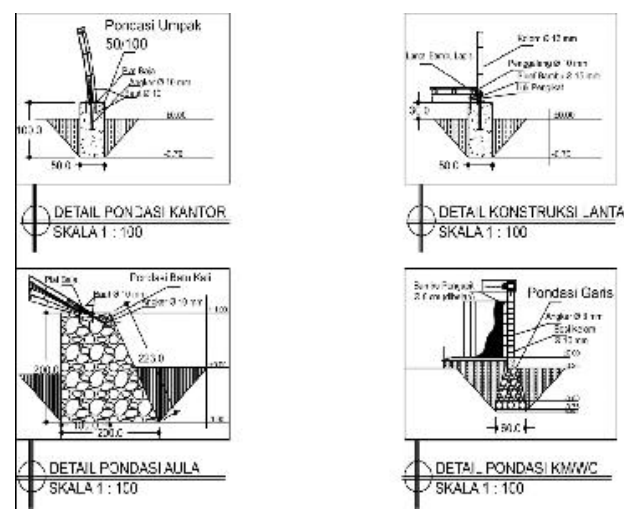

Gambar III.17: Detail Struktur. (Sumber: Data Pribadi)

\section{Potongan Kawasan}

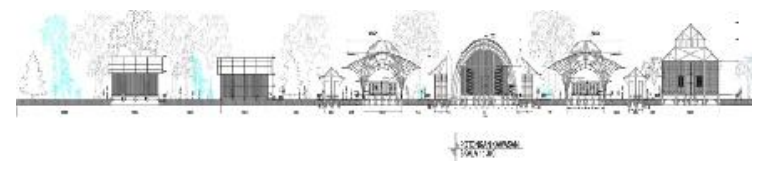

Gambar III.18: Potongan Kawasan. (Sumber: Data Pribadi)

\section{Tampak Utara Kawasan}

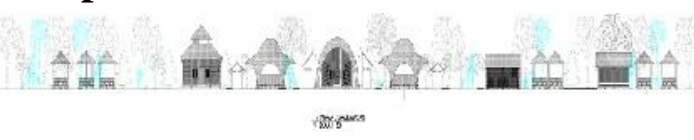

Gambar III.19: Tampak Utara Kawasan. (Sumber: Data Pribadi)

\section{Perspektif}

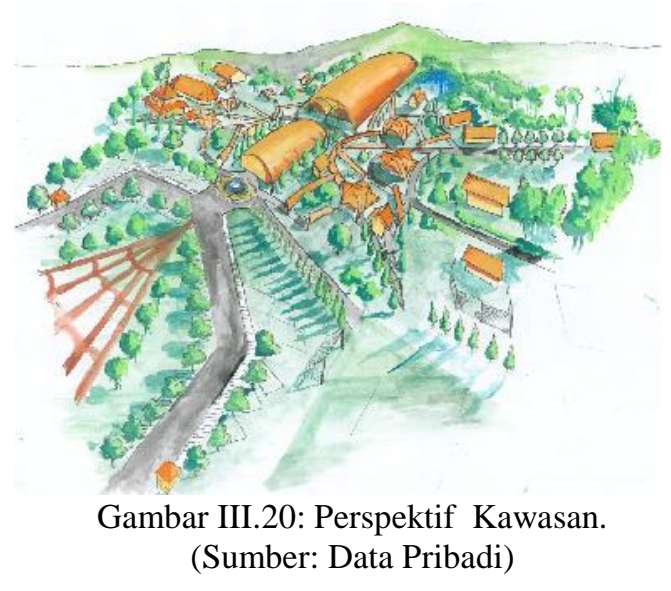

\section{KESIMPULAN}

Penggunaan alam sebagai media belajar memberikan manfaat besar dalam pendidikan yang dienyam siswa dan memperkuat pandangan islam karna kaitan ilmu pengetahuan dan kepedulian terhadap alam serta keberlajutannya. Hasil desain sekolah alam ini telah mengacu pada Konsep arsitektur hijau melalui tahapan analisis. Hasil desain ini baik bentuk, model, struktur yang digunakan disesuaikan dengan lingkungan dan konteksnya sehingga mempengaruhi kenyamanan, keamanan, keindahan serta keberlanjutan pada bangunan sekolah alam ini sehingga bisa diterima oleh lingkungannya dan hal ini dapat menjadi rekomendasi desain untuk pengembangannya. Penerapan konsep arsitektur berkelanjutan ini diantaranya 
diterapkan melalui keefisiensian penggunaan energy, efisiensi penggunaan lahan, potensi hijau tumbuhan dalam lahan yang dapat digantikan atau dimaksimalkan dengan berbagai inovasi yang telah diterapkan dalam desain sekolah alam dengan konsep arsitektur berkelanjutan.

\section{DAFTAR PUSTAKA}

Akmal, Imelda. 2011. Bambu Untuk Rumah Modern. Jakarta : Gramedia

Badan Pusat Statistik Kota Makassar. 2011.Makassar Dalam Angka 2011.Ud Areso:Makassar

Chatib, Munif. 2012. Sekolahnya manusia. Bandung : Kaifa

Depdiknas. 2001. Kamus Besar Bahasa Indonesia. Jakarta: Balai Pustaka

Frick, Heinz. 2004. Ilmu Konstruksi Bangunan Bambu. Yogyakarta : Kanisius

Hakim, Rumam dan Hardi Utomo. 2008. Komponen Perancangan Arsitektur Lansekap. PT Bumi Aksara: Jakarta

Neufert, Ernest. 1997. Data ArsitekJilid 1. Erlangga: Jakarta

Neufert, Ernest. 2002. Data ArsitekJilid II. Erlangga: Jakarta

Nikrirotin, Latifah. 2007. Tugas Akhir "Sekolah Pendidikan Dasar Terpadu di Semarang”. Semarang : Universitas Negeri Semarang

Nur Hafid, Ahmad. 2011. Tugas Semester IV "Modul Konstruksi Bambu". Surakarta : Universitas Sebelas Maret

Rohman, Arif. 2007. Makalah "Masalah Pembelajaran dan Pemecahannya" Yogyakarta : Universitas Negeri Yogyakarta 
Nature

National Academic Journal of Architecture 